ISSN 1112-9867

http://www.jfas.info

\title{
DESIGN AND EXPERIMENTAL STUDY OF A SOLAR SYSTEM FOR HEATING WATER UTILIZING A LINEAR FRESNEL REFLECTOR
}

\author{
M. Ghodbane ${ }^{1}$, B. Boumeddane ${ }^{1}$, N. Said ${ }^{2}$ \\ ${ }^{1}$ Mechanical Engineering Department, Saad DAHLAB University, Blida 1, Algeria \\ ${ }^{2}$ Consultant in CSP, Alger, Algeria
}

Received: 02 April 2016 / Accepted: 17 August 2016 / Published online: 01 September 2016

\begin{abstract}
This work presents a design and an experimental study of a linear Fresnel reflector solar with trapezoidal cavity. This prototype is used for heating the tap water. The reflector was designed, constructed and tested in mechanical engineering department, University of Blida 1, Algeria. Various combinations of reflecting mirrors were tried to achieve hot temperature at the concentration line. The absorber tube was made of copper; it was painted with black paint and covered by selective suitable surface. The quantity of heat available to the absorber tubes was evaluated and compared with 7,9 and 11 mirrors. The experimental works on the concentrator were accomplished within two days in the winter of 2015. Water temperature reached a maximum of $74{ }^{\circ} \mathrm{C}$ with eleven reflective mirrors. The maximum value of the thermal efficiency is $29.21 \%$. The results obtained are very encouraging for using linear Fresnel concentrator in the solar fields allocated to the domestics and industrial water-heaters.
\end{abstract}

Keywords: Solar energy; design, linear Fresnel reflector; thermal efficiency; solar water-heater.

Author Correspondence, e-mail: ghodbanemokhtar39@yahoo.com doi: http://dx.doi.org/10.4314/jfas.v8i3.8

(7) (8) Journal of Fundamental and Applied Sciences is licensed under a Creative Commons Attribution-NonCommercial 4.0 


\section{INTRODUCTION}

Solar energy is the energy of future, it is considered as one of the important potential modern energy sources; it is natural, non-polluting, permanent and free. It is a source of energy which directly converts to thermal energy and it exploited is in many domains [1, 2], especially in these domains:

- The solar refrigeration, such as electrical solar refrigeration (photovoltaic) [1, 3], refrigerate with vapor compression [4], Stirling refrigerators [5, 6], thermo acoustic electrical refrigeration [7], solar cooling [8-10]. As well as in the domain of thermal solar refrigeration [10, 11], such as the thermo-mechanical refrigeration [1]. In the domain of thermal solar Refrigeration, the thermal solar systems use solar heat rather than of solar electricity to produce the refrigerating effect. In these systems, the solar collectors of flats planes types are most commonly used. In the same way, there are other types of collectors such as the solar concentrators in the literatures [11].

- The production of thermal energy from the solar energy by the use of the solar collectors, the thermal solar energy may be used to produce steam or the hot liquids according to needs for use $[2,12]$, for example, to rotate an alternator, and as a result to produce electrical energy, this mechanism can be used in solar thermal power plants [13-16].

According to the use of solar collectors types, the thermal energy production knows many applications nowadays [2, 15, 17-19], by their innumerable economic and environmental interests $[17,18]$. Currently, the conservation of the energy resources become a priority in the planetary scales, in addition, considering the vertiginous request of energy, which pushed the specialists to find new methods, such as renewable energies (solar, wind and geothermic) [18, 20]. The improvement of the thermal performances of the solar collectors, reposes on several techniques, as the choice of the adequate forms and the parameters of design (geometrical, thermo physical and optical parameters).

Algeria has one of the most important solar layers in the world. The daily energy received on a horizontal surface of $1 \mathrm{~m}^{2}$ is higher than $5 \mathrm{KWh}$ on the major part of the national territory, approximately $1700 \mathrm{KWh} / \mathrm{m}^{2} /$ year in the north and $2700 \mathrm{KWh} / \mathrm{m}^{2} /$ year in the south of the country $[16,21]$.the potential of thermal solar energy represents 60 times of the energetic 
needs for Western Europe, according to Algerian ministry of Energy. For this, the Algerian North area choice to conduct this experimental study (region of Blida).

The technology of linear Fresnel reflector was invented by the French physicist Augustin-Jean FRESNEL (1788-1827), he was used this technology in the optical system of the marine indication headlights [22]. The work of Alessandro BATTAGLIA can be seen as the origin of the concentration technique by linear Fresnel reflectors (LFR) [23, 24]. Giovanni FRANCIA (1911-1980) was a Italian mathematician, he designed the first prototype of linear Fresnel Reflector with the downward facing aperture covered with glass honeycomb tubes at Marseille built in 1962, he got on the performance equal to $60 \%$ and steam water temperature equivalent to $450^{\circ} \mathrm{C}$ [25]. According to literatures, the optical performance of this collector is more than $30 \%$ and up to almost $40 \%[26,27]$.

Hot water in our daily lives is something that is necessary throughout the year; it is used industrially and domestically in large quantities. To reduce water heating costs, the whole world looking for energy to heat the water at the lowest cost. The world agrees that solar energy was the solution. Several studies were conducted on solar water-heaters; in 1971, H.P. GARG used flat-plate solar collector as a tool to get hot water, his experiments were conducted in the winter, where he got a water temperature between 48 and $55^{\circ} \mathrm{C}$ [28]. Y. M. DAKHOUL, R. E. SOMERS and R. D. HAYNES (1990) mentioned that there are three techniques to get hot water using solar energy; these techniques are photovoltaic arrays, solar dynamic systems and solar thermal collectors. The only technique that gives us hot water directly is a technique that relies on the use of solar thermal collectors [29]. In 1996, M. HUSSAIN and TANIA PARVEEN URMEE made two types of water-heaters in Bangladesh; the first one is made of two plastic bowls, and the second one is made of two ceramic vessels instead of plastic bowls; these types of water-heaters don't need feeding tubes water [30]. O. Helal, B. Chaouachi and S. Gabsi had installed a water-heater (integrated collector storage «ICS») consisting of single cylindrical horizontal tank placed in a three-piece parabolic reflector, the instantaneous efficiency of this prototype (ICS) was variable between $56 \%$ and $68 \%$ [31]. Also, both of MOBIN ARAB and ALI ABBAS conducted experiments to heat water using a concentric evacuated tube, the performance of this solar water-heaters 
was up to $84 \%$ [32].

In this work, a design and experimental of linear Fresnel reflector with trapezoidal cavity is described, this reflector was used as solar water heater. The objective of this paper is to analyze the experimental performances of the water heater using tap water in terms of real weather conditions for Blida region, Algeria. The efficacy of the device has been proven numerical simulation, based on the energy balance of the absorber tube. The numerical simulation details that proved the efficiency of the device have been published in the Journal: Case Studies in Thermal Engineering [33].

\section{EXPERIMENTAL}

\subsection{Design of the concentrator}

A linear Fresnel concentrator is a type of solar thermal collector that is straight in one dimension, it is simple and easy device compared to the other solar collectors of the same family [18], it has a simple architecture composed of: flat mirror reflector strips and the absorber tubes.

The mirrors are usually aligned on a north-south axis, and rotated to track the sun during it daily movement; they are oriented toward the sun to concentrate solar rays on the receiver tubes, which contains the liquid heated to high temperature by the absorbed energy; these hot fluids can be used for many purposes, domestic and industrial [34-36].

Figure 1 shows a photo of a linear Fresnel concentrator prototype, it was constructed in the Saad DAHLEB University, Blida 1 (beside the department of mechanics). The concentrator has a full surface opening of reflecting mirrors equivalent to $1.65 \mathrm{~m}^{2}$, with a pump to push the water in the open circuit and a storage tank to conserve the heated water. 


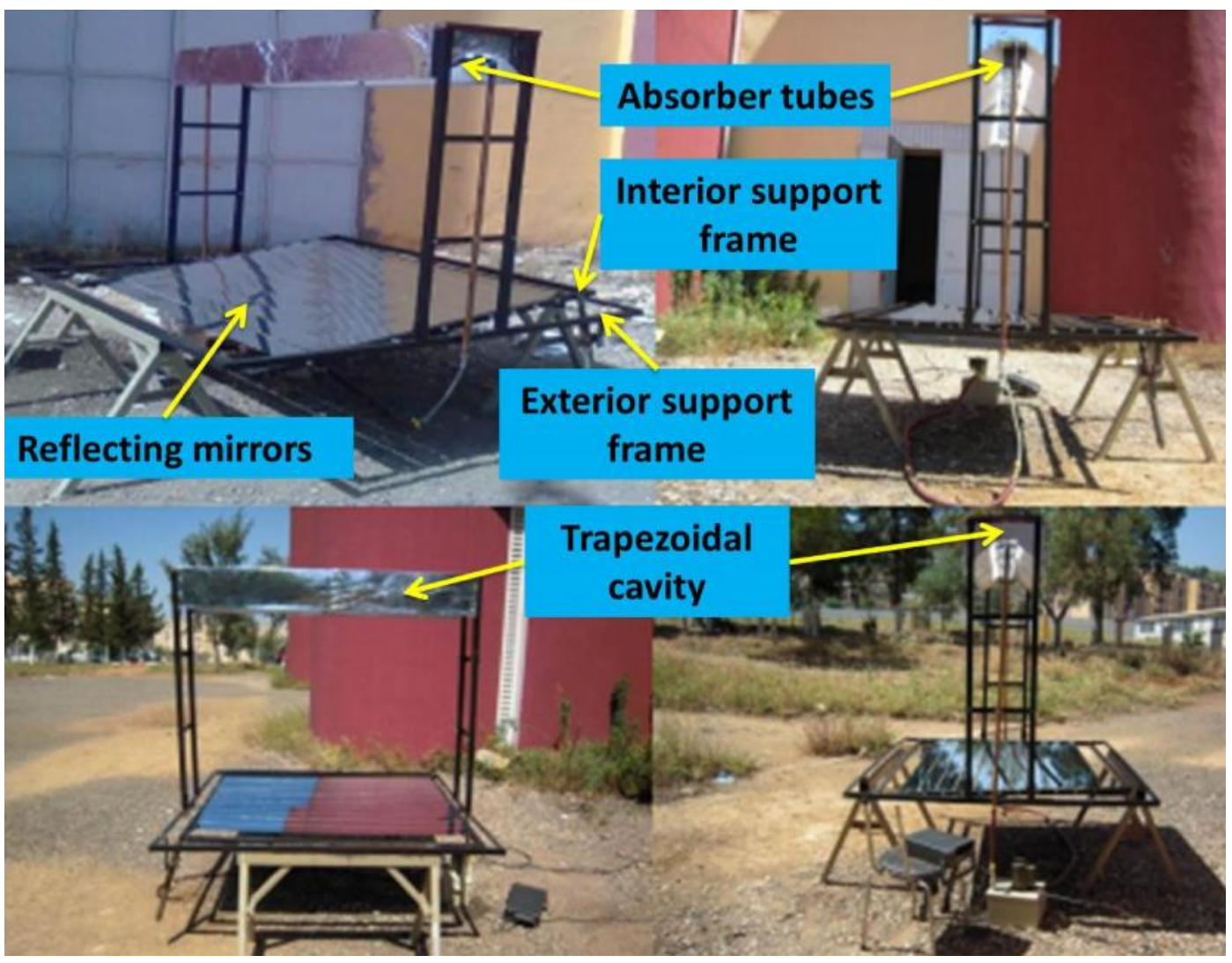

Fig.1. Photo of experimental device.

The concentrator (Fig. 1) is composed of five elements, they are as follows:

A. Exterior support frame: it's used to support the weight of the horizontal base with its reflecting mirrors and the absorber with all its components. It is made of four angle section metal bars (Length=1760 $\mathrm{mm}$, Width $=30 \mathrm{~mm}$, Height $=30 \mathrm{~mm}$ and thickness $=02 \mathrm{~mm}$ ).

B. Interior support frame: it's one of the most important components in this device because it bears the reflecting mirrors. It is consisted of four hollow square metal bars (Length= 1600 $\mathrm{mm}$, Width $=30 \mathrm{~mm}$, Height $=30 \mathrm{~mm}$ and Thickness $=1 \mathrm{~mm})$.

C. Reflecting mirrors: the experimental device contains eleven reflective mirrors strips (1500 $\mathrm{mm} \times 100 \mathrm{~mm}$ ) to redirect and concentrate the solar radiation towards a fixed absorber tubes.

D. Trapezoidal cavity: the trapezoidal cavity is a folded galvanized sheet (Length=2000 mm, Width $=1000 \mathrm{~mm}$ and thickness $=1.5 \mathrm{~mm}$ ) in the form of $(\mathrm{U})$. The vacuum inside it was filled with polystyrene $($ Length=3000 $\mathrm{mm}$, Width $=1000 \mathrm{~mm}$ and thickness $=100 \mathrm{~mm}$ ). We glued the white Formica plates (Length=1700 mm, Width $1=100 \mathrm{~mm}$, Width $2=125 \mathrm{~mm}$ and thickness $=4 \mathrm{~mm}$ ) on polystyrene with silicone and double-sided sellotape. The all gave us a 
trapezoidal shape. The figure 2 presents the dimensions of trapezoidal cavity with the four absorber tubes.

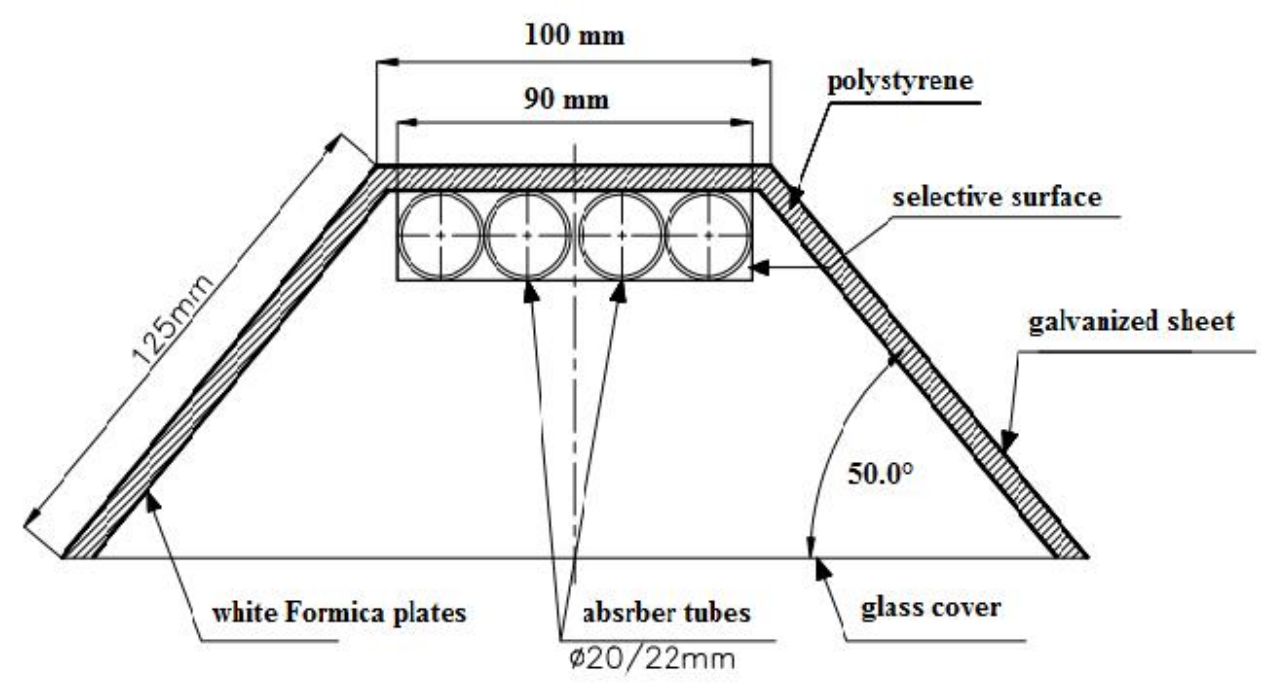

Fig.2. Geometry of trapezoidal cavity.

E. Absorber tubes: they are made of copper pipe $(\varnothing 20 / 22 \mathrm{~mm}$ and length of $1600 \mathrm{~mm})$ and placed in the cavity, there are four tubes; they are plated with painted black and covered by selective suitable surface. The selective layer was used on the absorber to increase its operation temperature and efficiencies [37]. The emissivity of selective surface is lower than 1 , since $(\varepsilon=1)$ for the ideal black body [38].

The focal distance (f) between the absorber tube and the central mirror is $1300 \mathrm{~mm}$. Table 1 is shows the special optical properties of reflecting mirrors and absorber tubes.

Table 1. The optical characteristics of the components of the solar concentrator.

\begin{tabular}{ll}
\hline Properties & Value \\
\hline absorption Coefficient of absorber tubes, $\alpha$ & 0.8 \\
\hline surface Reflectance of the mirror, $\rho_{\mathrm{m}}$ & 0.85 \\
\hline Emissivity of absorber tube, $\varepsilon_{\mathrm{A}}$ & 0.12 \\
\hline
\end{tabular}

The estimated of the making costs of the linear Fresnel concentrator is given in the table 2. 
Table 2. The costs of the device [EUR].

\begin{tabular}{lc}
\hline Element & Cost (EUR) \\
\hline Iron (hollow square, full round, coins) & 134.4 \\
\hline galvanized sheet & 25.20 \\
\hline reflecting mirrors & 13.44 \\
\hline Copper pipes with solder sticks & 99.54 \\
\hline Flexible glasses (Formica) & 9.24 \\
\hline Threaded rods of all sizes & 4.452 \\
\hline Self-adhesive (gray) & 6.72 \\
\hline insulation & 9.492 \\
\hline Workmanship for welding of copper tubes & 16.8 \\
\hline various accessories & 27.048 \\
\hline total & 346.332 \\
\hline
\end{tabular}

\subsection{Experimental measurements}

The tests were carried out at the university of Blida which is at an altitude of 260 meters, its latitude is of $36^{\circ} 28^{\prime} \mathrm{N}$ and its longitude is of $2^{\circ} 49$ 'E. The solar concentrator used in the experimental work is a simple design easy to install and easy to maintain. During the experiments, the hands were used to rotate each mirror toward the sun to track it depending on their inclination angle.

All climate conditions (direct solar radiation, wind speed and ambient temperature) were actually measured. A probe photovoltaic cell was used to measure the solar radiation, the cell made available to us by the REDC (renewable energy development center), an acquisition unit was used to read and convert the data. With regard to temperature measurement, the different temperatures (of the absorber tubes, the insulation and the water outside of the absorber tubes) were taken by thermocouples type $[\mathrm{K}]$; a data acquisition system (HYDRA type) was used for reading the temperature, it gives us the temperature value directly. Also, the digital thermometer (type $\mathrm{k}$ ) was used for measuring the temperature of the ambient temperature. As for the measurement of wind speed, the vane anemometer (Kimo LV 110) 
was used.

\subsection{Steps of the experiment}

Many of the tests were conducted on linear Fresnel concentrator during a period exceeding 15 days, in order to make sure that the collector was free of any leaks of a heat transfer fluid, and to show that the device is ready for use. Through these experiments the mass flow of tap water equal to $0.015[\mathrm{Kg} / \mathrm{s}]$.

The two days (January $22^{\text {nd }}, 2015$ and February $19^{\text {th }}, 2015$ ) were selected to conduct practical experiments, which correspond to a nice days with some passages of clouds and the solar illumination was enough to get acceptable results. The tests were carried out from 10:00 to $16: 00$

The experimental study comprises two parts. In the first part, the water was imprisoned in the absorber to determine the maximum values that could be reached by the concentrator. The tests are carried out with an ordinary black paint (absorption coefficient $=0.92$ and emissivity coefficient $=0.92$ ) and a selective coating (absorption coefficient $=0.93$ and emissivity coefficient=0.21). In the second part of the experiment, the water was flowing inside the absorber tubes in order to determine the performance of the prototype.

\subsection{Uncertainty analysis of experimental study}

The useful energy output of a collector of area $\left(\mathrm{A}_{\mathrm{C}}\right)$ is given below $[2,39,40]$ :

$$
q_{u s e f u l}=Q_{m} C_{F}\left(T_{f o}-T_{f i}\right)
$$

Where, $Q_{m}$ is the mass flow of the water with the intern to absorber $\left[\mathrm{Kg}^{3} / \mathrm{s}\right], \mathrm{C}_{\mathrm{F}}$ is the specific heat of the fluid $[\mathrm{J} / \mathrm{Kg} . \mathrm{K}], \mathrm{T}_{\mathrm{fo}}$ is the water outside temperature $\left[{ }^{\circ} \mathrm{C}\right]$ and $\mathrm{T}_{\mathrm{fi}}$ is the water outside temperature $\left[{ }^{\circ} \mathrm{C}\right]$.

The thermal efficiency is given the following equation $[2,27,39,40]$ :

$$
\eta=\frac{Q_{m} C_{F}\left(T_{f o}-T_{f i}\right)}{D N I A_{C}}
$$

With, $\mathrm{A}_{\mathrm{C}}$ is the total collector aperture area $\left(\mathrm{m}^{2}\right)$ and DNI is the Direct-normal irradiance $\left[\mathrm{W} / \mathrm{m}^{2}\right]$.

Solar energy which descends on the absorber tube is not entirely transmitted to the fluid; a part is dissipated in the form of thermal losses between the absorber and ambient air. The 
thermal loss ratio is given by the following relation [41]:

$$
U_{L}=\varepsilon_{\mathrm{A}} \sigma\left(T_{A}^{2}+T_{a m b}^{2}\right)\left(T_{A}+T_{a m b}\right)
$$

With, $\sigma$ is Stefan-Boltzmann constant $\left(\sigma=5.6689710-8 \mathrm{~W} / \mathrm{m}^{2} \mathrm{~K}^{4}\right), \varepsilon_{\mathrm{A}}$ is the absorber emissivity, $\mathrm{T}_{\mathrm{A}}$ is the absorber temperature $[\mathrm{K}]$ and $\mathrm{T}_{\mathrm{amb}}$ is the ambient temperature $[\mathrm{K}]$.

\section{RESULTS AND DISCUSSION}

\subsection{Direct -normal irradiance}

The figure 3 presents the measured values of direct solar radiation depending on time for both days of the experiment.

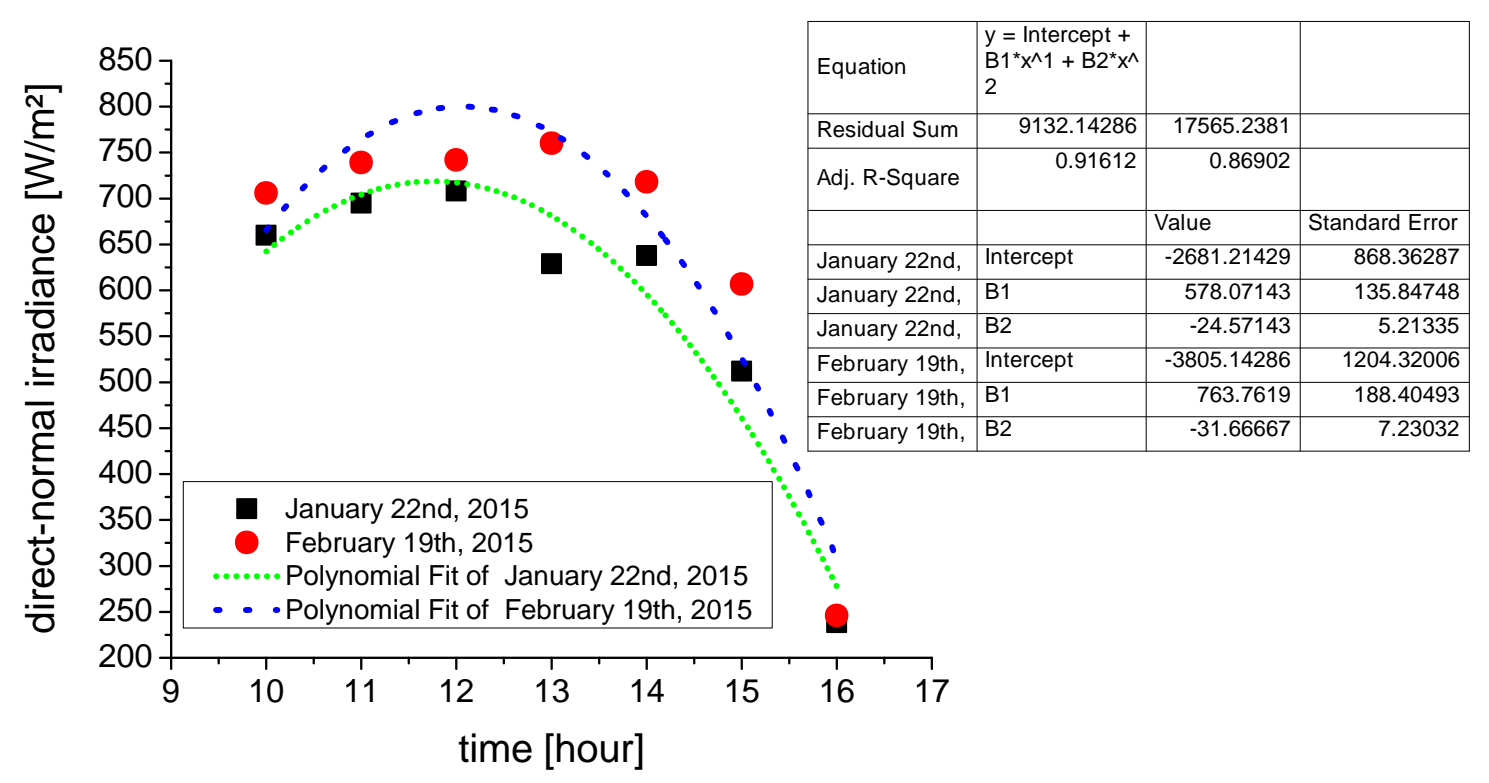

Fig.3. Measured values of the direct-normal irradiance.

The maximum value of solar radiation was registered on February $19^{\text {th }}$ at $13: 00$, it's equal to $760\left[\mathrm{~W} / \mathrm{m}^{2}\right]$, and the minimum value was registered on the January $22^{\text {nd }}$ at $16: 00$, it's equal to $238\left[\mathrm{~W} / \mathrm{m}^{2}\right]$. While doing experiments was observed crossing the little clouds, specifically between 12:00 o'clock and 14:00 o'clock for the January $22^{\text {nd }}$. 


\subsection{Climatic conditions}

Large numbers of elements found in the environment of experience a significant impact on results, such as ambient temperature and the wind speed. The figure 4 shows the measured values of the air temperature and the wind speed during the experiment days.

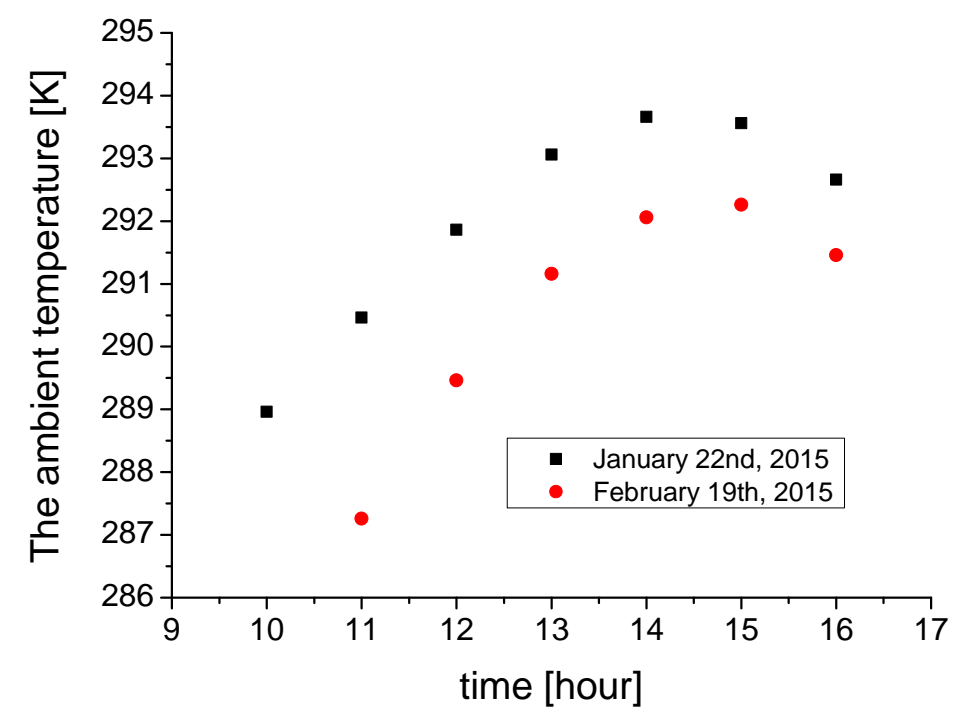

Fig.4. Measured values of ambient temperature.

The figure 5 shows the measured values of the wind speed during the experiment days.

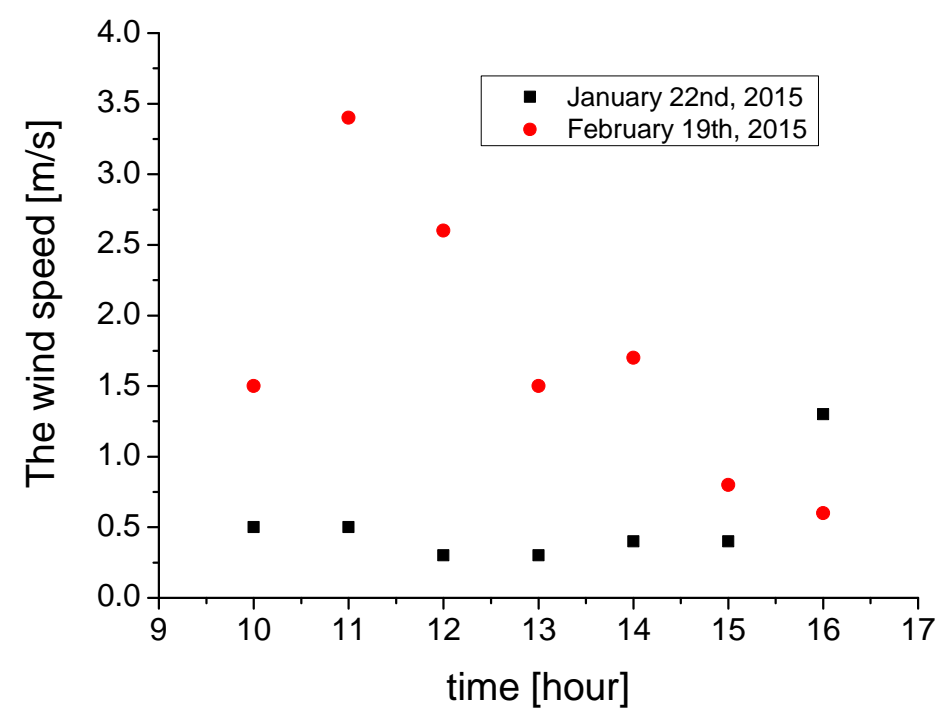

Fig.5. Measured values of wind speed.

\subsection{Thermal efficiencies}

Optical efficiency of the linear Fresnel concentrator with eleven reflective mirrors is $29.5 \%$. 
The water temperature $\left(\mathrm{T}_{\mathrm{fi}}\right)$ at the inlet of the absorber tube is equal to $12{ }^{\circ} \mathrm{C}$. The table 3 shows the evolution of thermal efficiency according to the number of reflecting mirrors within an hour of the time (60 minutes) in the same experimental conditions.

Table 3. Comparison between the thermal efficiency in terms of the mirrors number.

\begin{tabular}{llll}
\hline $\begin{array}{l}\text { Number of } \\
\text { mirrors }\end{array}$ & $\begin{array}{l}\text { Reflective surface (effective) } \\
{\left[\mathbf{m}^{2}\right]}\end{array}$ & $\begin{array}{l}\text { thermal } \\
\text { efficiency } \\
\text { (black paint) } \%\end{array}$ & $\begin{array}{l}\text { thermal efficiency } \\
\text { (selective }\end{array}$ \\
\hline 7 & surface) $\%$ \\
\hline 9 & 0.747 & 19.87 & 20.65 \\
11 & 0.9435 & 24.32 & 27.13 \\
\hline
\end{tabular}

According to the previous table was noticed that the covered absorber with selective surface gave the best efficiency compared to absorbers with black paint (the absorber with selective surface has a high absorption coefficient and a low emission coefficient). Because of that, in the experiment works used the absorber tubes with selective surface. The variation of the experimental thermal efficiency a function of time is shown in the figure 6.

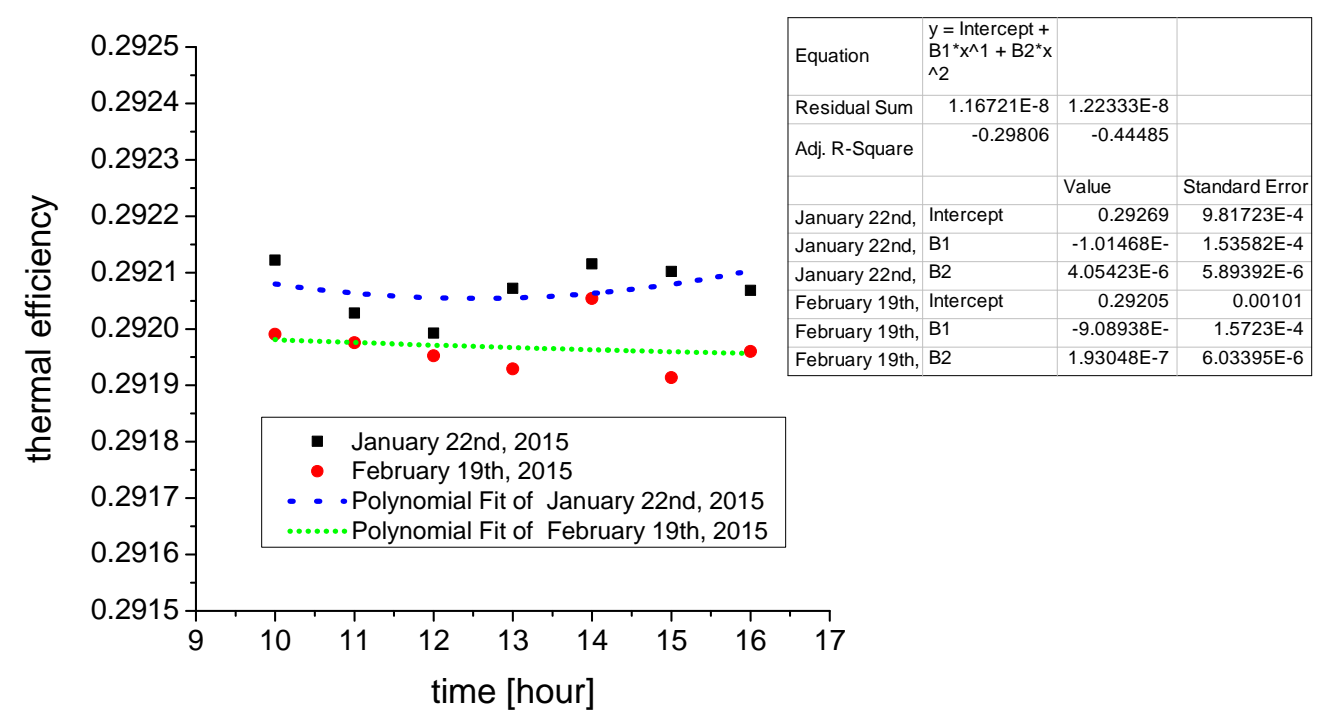

Fig.6. Evolution of experimental thermal efficiencies a function of time.

Practically, the curves are almost similar over the two days of experience, which shows good 
tracking of solar radiation during the experiments. An experimental efficiency of $29.2054 \%$ was registered at $14: 00$ on February $19^{\text {th }}$ and $29.212 \%$ at $14: 00$ on January $22^{\text {nd }}$. Then the efficiency decreases slightly. The thermal efficiencies of the reflectors depend on its thermal characteristics (lower losses) and optical (the degree of concentration and increase in useful solar gains). In addition, the optimal position (tilt of the concentrator) of the concentrator ensures a good performance and less heat loss. Therefore, the interest for concentration ratio is a necessary factor.

\subsection{Evolution of temperature}

With regard to the first part of the experimental work any the research on stagnation temperature after imprisonment of the water in the absorber for the purpose of determining the maximum temperature values that can be achieved with the concentrator. In this part, the experiences were conducted in the first time using absorber tubes with black paint only; the experiment began on 11:00, where the primary temperature of the water was equal to 291.81 $[\mathrm{K}]$, the ambient temperature equal to $300.16[\mathrm{~K}]$, and the solar radiation equal to $615\left[\mathrm{~W} / \mathrm{m}^{2}\right]$. The experiments ended at 13:00, where the solar radiation is equal to $708\left[\mathrm{~W} / \mathrm{m}^{2}\right]$. It was observed that the fluid temperature varies proportionally with the time of exposure to the sun; this variation is linear and increasing up to a temperature of $103{ }^{\circ} \mathrm{C}$. The average temperature of the absorber tubes at 13:00 had reached to $121^{\circ} \mathrm{C}$.

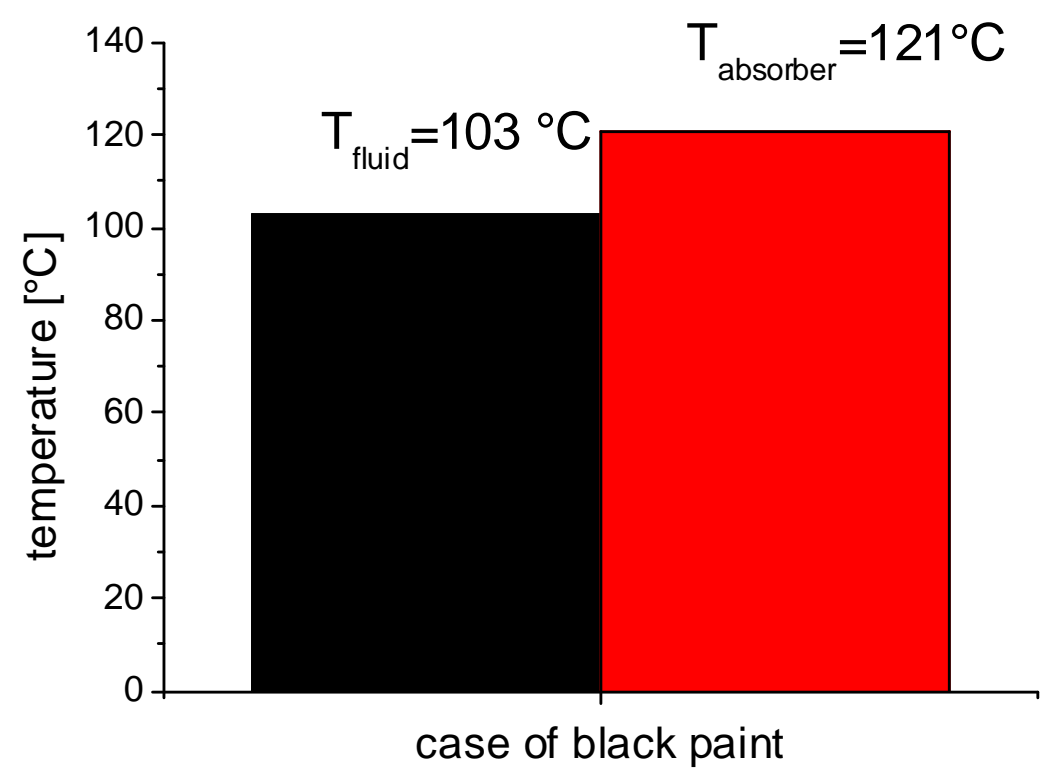

Fig.7. Stagnation temperatures in case of the black paint. 
After the value of $103{ }^{\circ} \mathrm{C}$, the temperature variation becomes zero, the maximum temperature does not exceed the value $103{ }^{\circ} \mathrm{C}$ regardless of the exposure time, it means that the fluid stagnation temperature equal to $103^{\circ} \mathrm{C}$, it was difficult to exceed this value; this is due to heat loss which equalizes the incident energy.

Regarding to the absorber tubes encased with selective surface, the test initiated at 11:00, where the primary temperature of the water was equal to $291.66[\mathrm{~K}]$, the ambient temperature equal to $303.16[\mathrm{~K}]$, and the solar radiation equal to $650\left[\mathrm{~W} / \mathrm{m}^{2}\right]$. The test finished at 13:00, where the solar radiation is equal to $745\left[\mathrm{~W} / \mathrm{m}^{2}\right]$. We noticed that the fluid temperature varies growing the course of time; this variation of fluid temperature is linear and increasing until $112^{\circ} \mathrm{C}$; with regard to the absorber tube, the average value of absorber tubes temperature equal to $202^{\circ} \mathrm{C}$.

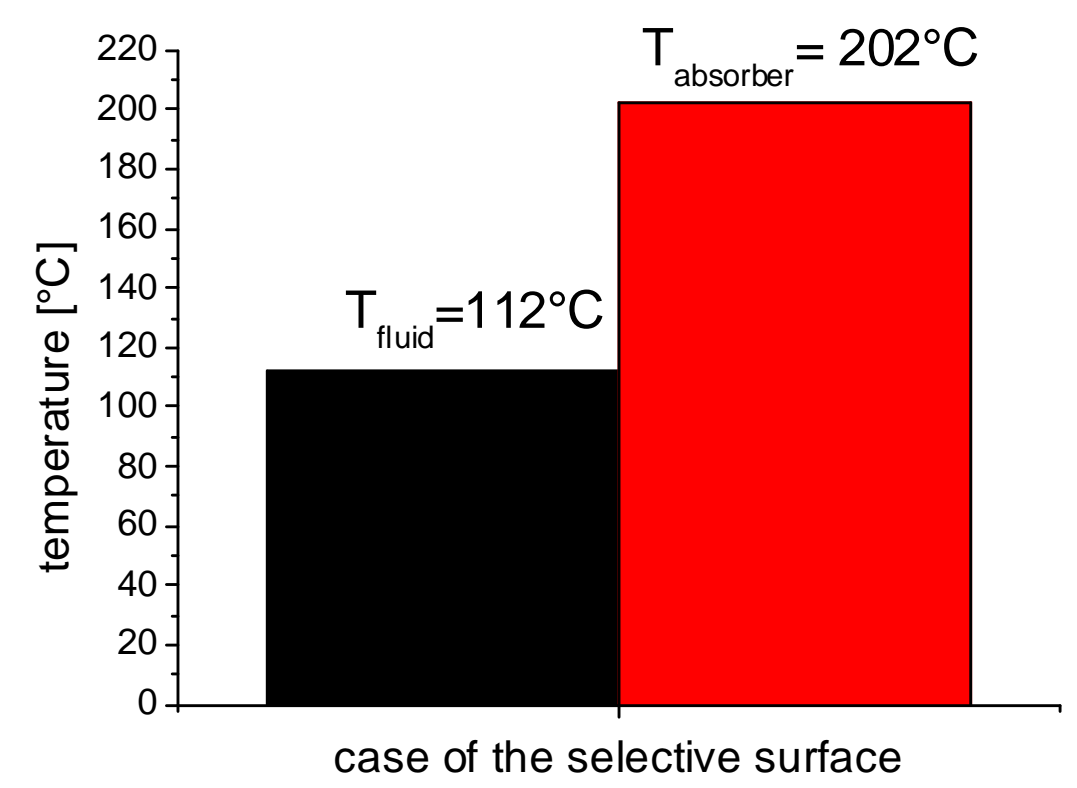

Fig.8. Stagnation temperatures in case of the selective surface.

These results can be explained as follows, the high absorption capacity of the receiver with selective surface to the visible solar radiation and low emissivity for infrared radiation wavelength; in which the receiver with selective surface is possible to keep the greater part of the incident solar energy and to not lose very little heat radiation in the wavelength when the absorbent surface becomes hot. As the water temperature exceeded $100{ }^{\circ} \mathrm{C}$, it means to be sucking the steam inside the absorber tubes (there is a change in the phase of the water from liquid to gas), any the access to water vapor without costs (free). 
In the second part of the experiment, the water was percolated and moving inside the absorber tubes In order to identify and evaluate the performance of the concentrator. The tests are made with selective surface. The inlet temperature of water $\left(\mathrm{T}_{\mathrm{fi}}\right)$ within the absorber tubes is $12{ }^{\circ} \mathrm{C}$. Therefore, it is easy to show that the variation of the different temperatures especially depends on the incident solar power and the surrounding weather conditions.

From 10:00 to 16:00 when the sun is set fair, the concentrator does its job. The figure 9 represents the variation of the absorber's temperature in terms of the times during the two days of testing.

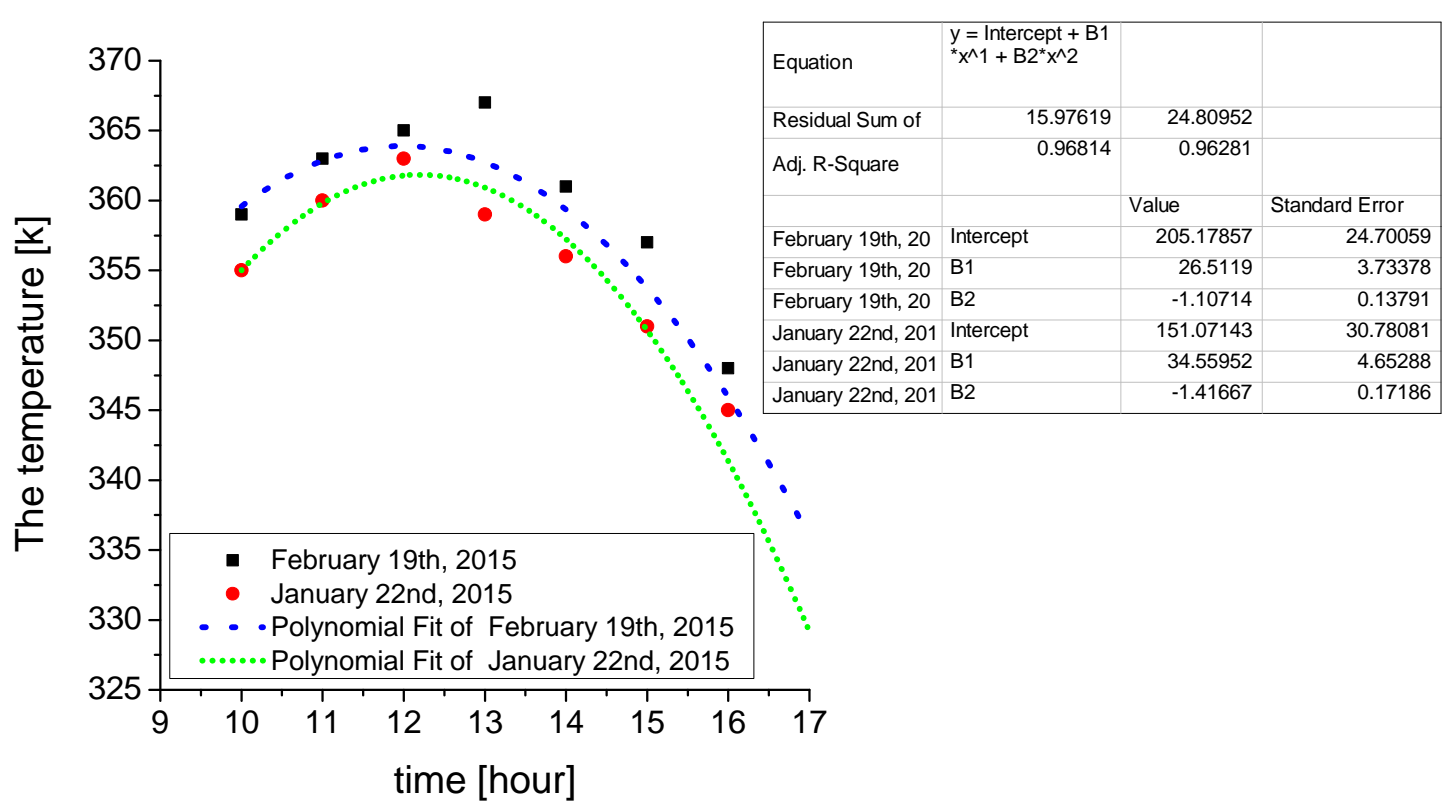

Fig.9. Evolution of the absorber tubes temperature a function of time.

From the figure 9, we note that the absorber's temperature was varied between $355[\mathrm{~K}]$ and $363[\mathrm{~K}]$ between 10:00 and 12:00 for the January $22^{\text {nd }}$, after this time, It was observed that a decrease in temperature, so as to reach at $16: 00$ to $345[\mathrm{~K}]$. The same remarks for the day of February $19^{\text {th }}$, where the highest absorber's temperature registered at 13:00, it was estimated to $367[\mathrm{~K}]$.

The water's temperature $\left(T_{f o}\right)$ is very close to the absorber tubes temperature $\left(T_{A}\right)$ which referred to in the figure 9, this difference is probably due to the fact that there are thermal losses in the absorber, but it's still very low. Evolution of the water temperature at the outlet of the absorber tubes is shown in the figure 10. 


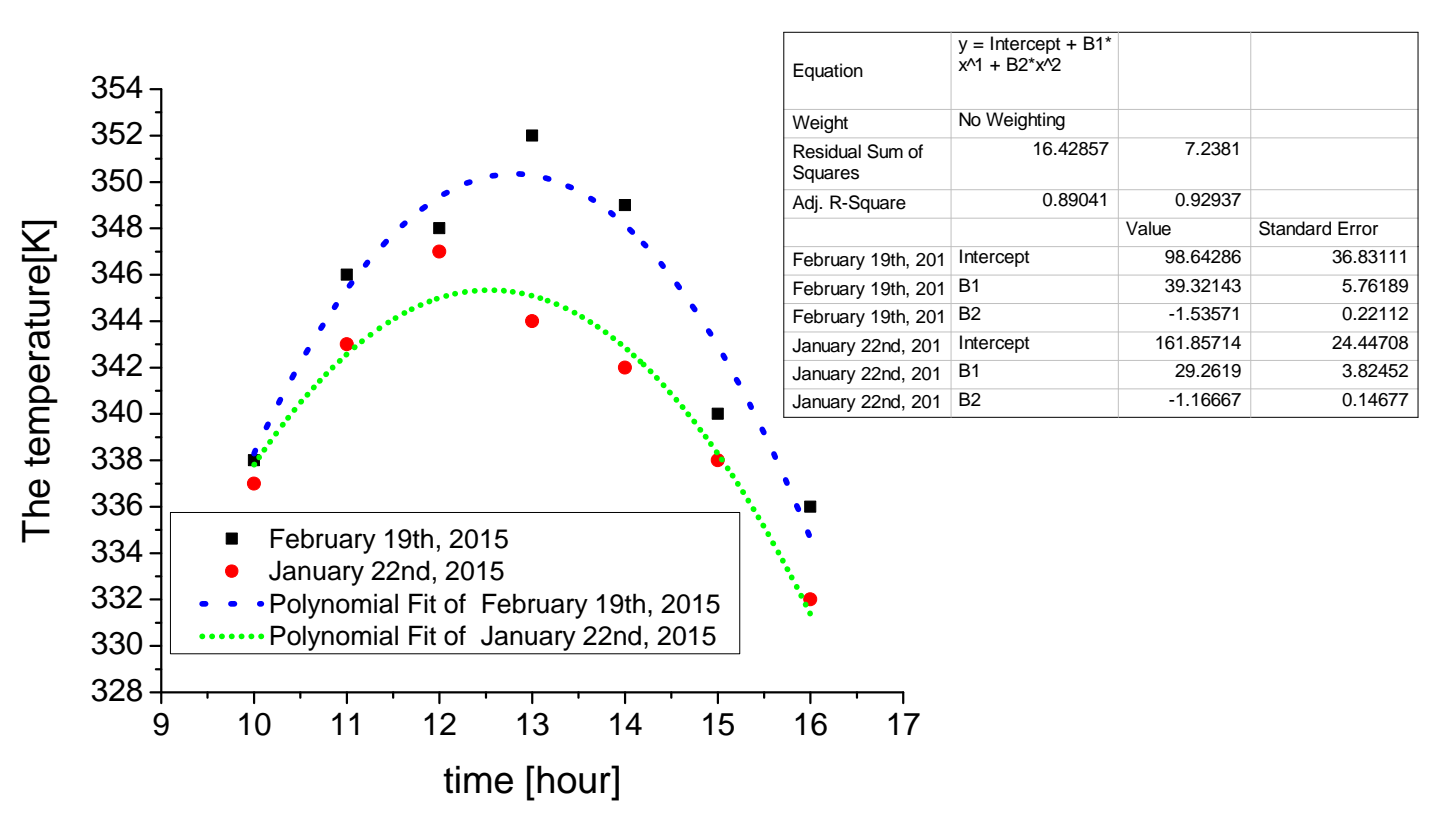

Fig.10. Evolution of the water's temperature at the outlet of the absorber tubes a function of time.

Through graphs curves, there is an increasing in the water's temperature between 10:00 and 12:00 for the day of January $22^{\text {nd }}$, where the water temperature reached to $347[\mathrm{~K}]$. For the day of February $19^{\text {th }}$, it was reached $352[\mathrm{~K}]$ at 13:00, after that, it was noted that a decrease in water's temperature, this decrease due to a reduction in the solar radiation after midday.

As previously noted, there is not a much difference between the water's temperature and the absorber's tubes temperature, which can be justified by the high absorption power of the absorber tubes for visible solar radiation and low emissivity for the infrared radiation of long wavelength, and this was due to the use of selective coating on the receiver tubes that increase the absorption efficiency of the absorber. Here the role of selective surface is clear, it is possible to keep the greater part of the incident solar energy and not lose it except of very little heat radiation in the wavelength when the absorbent surface becomes hot. In addition, the water's temperature is less than the absorber's tubes temperature for the two days, because the inner face of the absorber absorbs infrared radiation, which undergoes a rise in temperature $\left(\mathrm{T}_{\mathrm{A}}\right)$ (greenhouse effect phenomena). Therefore, the temperature of the outer side is lower and it is close to the ambient medium subjected mainly to the wind speed, creating convection to the outer of the absorber. Therefore, the Weather information (ambient temperature and wind speed) are very important, because it has a direct impact on the 
performances of the solar collector.

Fluid temperature can be increased by increasing the effective surface of reflecting mirrors $\left(S_{e}\right)$, where they can get water vapor during the water flow inside the absorber tubes, through the use of the same solar concentrator, but with fifteen reflective mirrors (1500 mm $\times 100 \mathrm{~mm}$ ), which means the use of reflecting effective area is equal to $1.521 \mathrm{~m}^{2}$.

\subsection{Heat loss coefficient}

The incident solar energy absorbed by the absorber tubes, is not fully transmitted to the water, there is a part is dissipated as heat loss between the absorber and the ambient. Heat loss coefficient $\left(\mathrm{U}_{\mathrm{L}}\right)$ calculation is insatiable factor in our study. The figure 11 describes the change in this coefficient in terms of the difference between the temperature of the absorber tubes $\left(\mathrm{T}_{\mathrm{A}}\right)$ and the ambient $\left(\mathrm{T}_{\mathrm{amb}}\right)$.

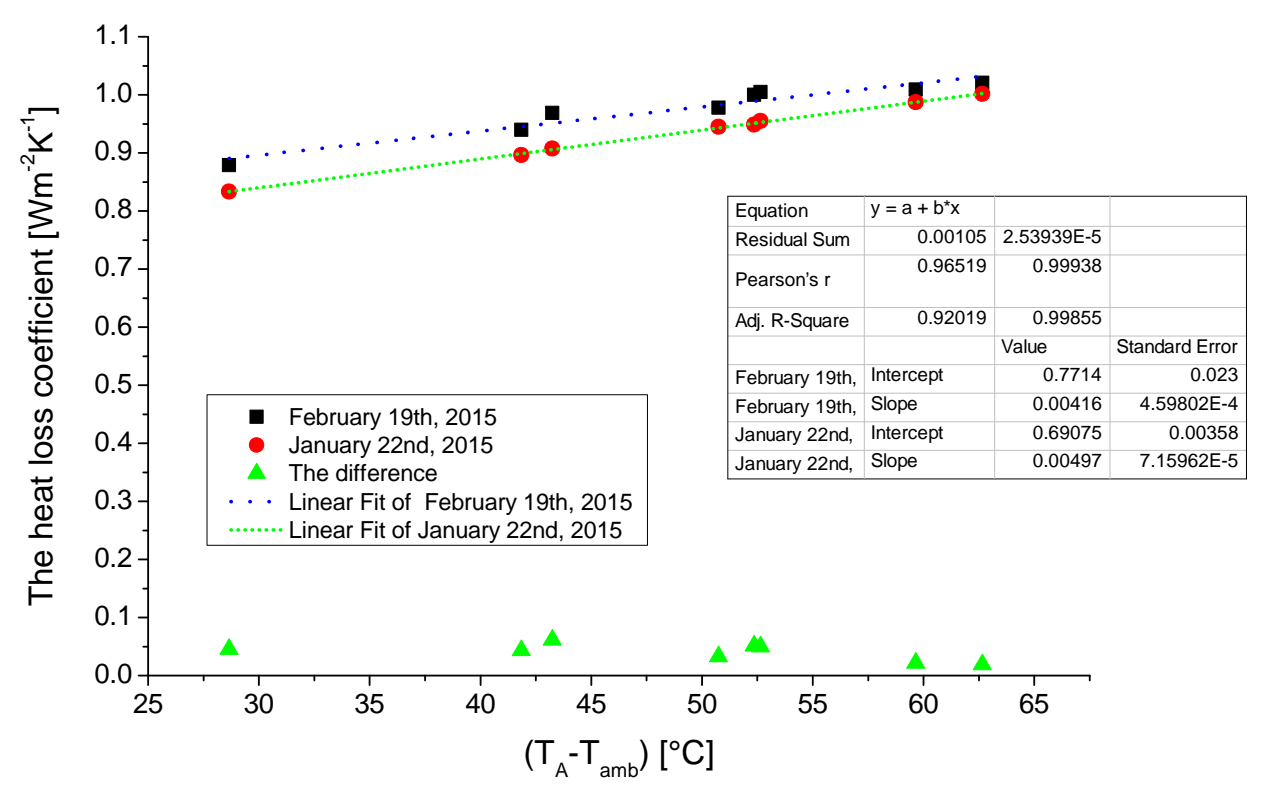

Fig.11. Evolution of the thermal losses coefficient.

The absorber tubes are the heart of the thermal losses. The heat losses increase with the increase in the absorber temperature. We make announce that, an emissivity of the absorber in the vicinity of 0.12 could reduce greatly the thermal losses by radiation; this is one of the advantages use of selective surfaces (selective coating). In addition, to reduce the thermal losses coefficient, we can do that using absorber tubes with a glass tube, In order to reduce the losses by convection between absorber tubes and outdoor air around him. There is another technology that helps to reduce the convection coefficient; this technique is creation of the 
vacuum between absorber tube and glass tube. In previous study, this technique of using absorber tubes with glass tubes was used by us, but using a solar concentrator of a kind 'parabolic trough', where results of the numerical studies were very encouraging $[15,16]$. Therefore, the correlation for the average thermal loss coefficient of the linear Fresnel reflector experimentally used in this study is:

- January $22^{\text {nd }}, 2015$

$$
\begin{aligned}
U_{L}=-7 \times 10^{-7}\left(T_{A}-T_{a m b}\right)^{3}+9 \times 10^{-5}\left(T_{A}-T_{a m b}\right)^{2} & \\
& +0.001\left(T_{A}-T_{a m b}\right)+0.07458
\end{aligned}
$$

With a coefficient of determination $\left(\mathrm{R}^{2}\right)$ on the graph equal to 0.9989 .

- $\quad$ February $19^{\text {th }}, 2015$

$$
\begin{aligned}
U_{L}=-9 \times 10^{-7}\left(T_{A}-T_{a m b}\right)^{3}+10^{-4}\left(T_{A}-T_{a m b}\right)^{2} & \\
& +0.0017\left(T_{A}-T_{a m b}\right)+0.07474
\end{aligned}
$$

With a coefficient of determination $\left(\mathrm{R}^{2}\right)$ on the graph equal to 0.9978 .

When comparing the values of heat loss coefficient of this study with the results presented in earlier Scientific's literatures for linear Fresnel collectors [42], it noted the existence of substantial convergence between the results. Through form figure 11, the heat loss coefficient of linear Fresnel concentrator is limited between 0.8 and $1.05\left[\mathrm{~W} / \mathrm{m}^{2} . \mathrm{K}\right]$.

Based on the experimental results confirmed the results of the numerical simulation [33], can be used the linear Fresnel concentrator as a Solar device for heating water for homes and factories (industrial and domestic use). This type of heating usually used to complete the water-heaters types exploiting other energy sources (electricity, fossil fuels, etc.), and under certain conditions it can replace them completely. The solar water-heater is an economical, efficient and sustainable. The solar water-heater uses available solar energy; this energy is a lasting source that will contribute to the energy independence. The manufactures and the users of a solar water-heater minimize pollution and minimize issuance of greenhouse effect gases. 


\section{CONCLUSION}

The purpose of this study is a design of solar water-heater depends on the linear Fresnel reflector (LFR) as a solar concentrator. The experimental device was installed and tested at the Institute of Mechanical Engineering, University of Blida. Through the results obtained, it was observed that:

- The cost per unit area of the linear Fresnel reflector surface is acceptable, because it is simple to install and easy to maintain.

- The thermal efficiency of the experimental device of linear Fresnel concentrator is acceptable, it was exceeded $29 \%$ and it reached $29.21 \%$ on January $22^{\text {nd }}, 2015$.

- The stagnation temperature of the fluid is higher than $100\left[{ }^{\circ} \mathrm{C}\right]$; this shows that we can have vapor without power consumption and with a low level of gas emission (like $\mathrm{CO}_{2}$ ).

- Wtith eleven reflector mirrors, the water's temperature reached up to $74^{\circ} \mathrm{C}$ with a solar radiation equal to $760 \mathrm{~W} / \mathrm{m}^{2}$. The results clearly show that water temperature came out from the absorber tubes has a direct relation with the geometric parameters, the solar flux and climatic parameters.

The obtained results are very encouraging to continue to improve this device and to apply it on the industrial and domestic fields such as the solar water-heater. This device can be used as a thermodynamic process that uses a solar energy to heat water; it is an economic process used permanent and clean energy.

\section{REFERENCES}

[1] KIM D S, INFANTE FERREIRA C A. Solar refrigeration options - a state-of-the-art review, International Journal of Refrigeration, 2008, 31, 3-15. http://dx.doi.org/10.1016/j.ijrefrig.2007.07.011

[2] KALOGIROU S A. Performance of Solar Collectors, in solar energy engineering: processes and systems, 1st ed., Academic Press is an Imprint of Elsevier, 2009.

[3] FANNEY A H, DOUGHERTY B P, DAVIS M W. Measured performance of building integrated photovoltaic panels, Journal of Solar Energy Engineering, Transactions of the 
ASME, 2001, 123, (3), 2001, 187-193. http://dx.doi.org/10.1115/1.1385824

[4] RUDISCHER R, WASCHULL J, HERNSCHIER W, FRIEBE C. Available solar cooling applications for different purposes, presented at Proceedings of International Conference Solar Air Conditioning, Bad Staffelstein, Germany, 2005.

[5] EWERT M K, AGRELlA M, DEMONBRUN D, FRAHM J, BERGERON D J, BERCHOWITZ M D. Experimental evaluation of a solar PV refrigerator with thermoelectric, Stirling, and vapour compression heat pumps, presented at Proceedings of ASES Solar 98 Conference, Albuquerque, USA, 1998.

[6] BERCHOWITZ D M, MCENTEE J, WELTY S. Design and testing of a $40 \mathrm{~W}$ freepiston Stirling cycle cooling unit, presented at Proceedings of 20th International Congress of Refrigeration, Sydney, Australia, 1999.

[7] GARDNER C, LAWN C. Design of a standing-wave thermoacoustic engine, presented at 16th International Congress on Sound and Vibration, 5-9 July, Krakow, Poland, 2009.

[8] ALlOUHI A, KOUSKSOU T, JAMIL A, BRUEL P, MOURAD Y, ZERAOULI Y. Solar driven cooling systems: An updated review, Renewable and Sustainable Energy Reviews, 2015, 44, 159-181. http://dx.doi.org/10.1016/j.rser.2014.12.014

[9] HE T, ZHANG X, WANG C, WANG M, LI B, XUE N, SHIMIZU K, TAKAHASHI K, WU Y. Application of solar thermal cooling system driven by low temperature heat source in China, Energy Procedia, 2015, 70, 454-46. http://dx.doi.org/10.1016/j.egypro.2015.02.147

[10] HASAN A A, GOSWAMI D Y, VIJAYARAGHAVAN S. first and second law analysis of a new power and refrigeration thermodynamic cycle using a solar heat source, Solar Energy, 2002, 73, 385-393. http://dx.doi.org/10.1016/S0038-092X(02)00113-5

[11] FADAR A E, MIMET A, PÉREZ-GARCYA M. Study of an adsorption refrigeration system powered by parabolic trough collector and coupled with a heat pipe, Renewable Energy, 2009, 34, 2271-2279. http://dx.doi.org/10.1016/j.renene.2009.03.009

[12] GHODBANE M, BOUMEDDANE B, MOUMMI N, LARGOT S, BERKANE H. Study and numerical simulation of solar system for air heating, J Fundam Appl Sci, 2016, 8, (1), 41-60. http://dx.doi.org/10.4314/jfas.v8i1.3

[13] WIKIPEDIA. Energie solaire thermique, Web site: 
[14] http://fr.wikipedia.org/wiki/\%C3\%89nergie_solaire_thermique ,4 juin 2015.

[15] GHODBANE M, BOUMEDDANE B, LARGOT S. Etude optique et thermique d'un concentrateur cylindro-parabolique en site d'Alger, Algérie, presented at IXth International Congress on Renewable Energy and the Environment, Djerba, Tunisie, 18-20 March 2015. http://dx.doi.org/10.13140/RG.2.1.1609.5763

[16] GHODBANE M, BOUMEDDANE B, LARGOT S. Simulation Numérique d'un Concentrateur Cylindro-Parabolique en El Oued, Algérie, International Journal of Scientific Research \& Engineering Technology (IJSET), 2015, 3, (2), 68-74.

[17] GHODBANE M, BOUMEDDANE B. Numerical modeling of a parabolic trough solar collector at bouzaréah, Algeria, Int J Chem Pet Sci, 2015, 4, (2), 11-25.

[18] ROMERO-ALVAREZ M, ZARZA E. Concentrating Solar Thermal Power, in Handbook of Energy Efficiency and Renewable Energy, L. Taylor \& Francis Group, 2007, pp. $1-92$

[19] KALOGIROU S A. Solar thermal collectors and applications, Progress in Energy and Combustion Science, 2004, 30, 231-295. http://dx.doi.org/10.1016/j.pecs.2004.02.001

[20] AL-KHARABSHEH S, GOSWAMI D Y. Experimental study of an innovative solar water desalination system utilizing a passive vacuum technique, Solar Energy, 2003, 75, 395401. http://dx.doi.org/10.1016/j.solener.2003.08.031

[21] SØRENSEN B. The Individual Energy Sources, in Renewable Energy: Its physics, engineering, use, environmental impacts, economy and planning aspects, 3rd ed., Elsevier Academic Press, 2004.

[22] Energy minister of Algeria, Potentiels National des Énergies Renouvelables, Web site: http://www.mem-algeria.org/, 2015.

[23] HABERLE A. Linear Fresnel Collectors, Robert A. Meyers (ed.) Encyclopedia of Sustainability Science and Technology, 2012, 72-78. http://dx.doi.org/10.1007/978-1-44190851-3

[24] VEYNANDT F. Cogénération héliothermodynamique avec concentrateur linéaire de Fresnel: modélisation de l'ensemble du procédé, Institut National Polytechnique de Toulouse, Université de Toulouse, 2011, pp. 213. 
[25] SILVI C. Italian contribution to CSP with flat reflectors, presented at ISES Solar World Congress, Kassel Germany 28 Aug. - 02 Sept. 2011.

[26] KALOGIROU S A. Fresnel collectors, in Solar Energy Engineering: Processes and Systems, 1st ed., Library of Congress Cataloging-in-Publication Data, 2009, pp.152.

[27] GARCIA P. Outils d'évaluation technico-économique et d'aide à la conception des centrales solaires thermodynamiques du futur, Université de Perpignan, 2007, pp.35.

[28] NEGI B S, MATHUR S S, KANDPAL T C. optical and thermal performance evaluation of a linear Fresnel reflector solar concentrator, Solar \& Wind Technology, 1989, 6, 589-593. http://dx.doi.org/10.1016/0741-983X(89)90095-7

[29] GARG H P. Design and performance of a large-size solar water heater, solar energy, 1973, 14, 303-312. http://dx.doi.org/doi:10.1016/0038-092X(73)90097-2

[30] DAKHOUL Y M, SOMERS R E, HAYNES R D. A conceptual design for a space-based solar water heater, Solar Energy, 1990, 44, 161-171. http://dx.doi.org/10.1016/0038092X(90)90080-V

[31] HUSSAIN M, URMEE T P. Design and fabrication of low cost solar water heaters, Renewable Energy (WREC), 1996, 9, 609-612. http://dx.doi.org/10.1016/0960-1481(96)88362-5 [32] HELAL O, CHAOUACHI B, GABSI S. Design and thermal performance of an ICS solar water heater based on three parabolic sections, Solar Energy, 2011, 85, 2421-2432. http://dx.doi.org/10.1016/j.solener.2011.06.021

[33] ARAB M, ABBAS A. Model-based design and analysis of heat pipe working fluid for optimal performance in a concentric evacuated tube solar water heater, Solar Energy, 2013, 94, 162-176. http://dx.doi.org/10.1016/j.solener.2013.03.029

[34] GHODBANE M, BOUMEDDANE B, SAID N. A linear Fresnel reflector as a solar system for heating water: theoretical and experimental study, Case Studies in Thermal Engineering, 2016, 8, 176-186. http://dx.doi.org/10.1016/j.csite.2016.06.006

[35] GRENA R, TARQUINI P. Solar linear Fresnel collector using molten nitrates as heat transfer fluid, Energy, 2011, 36, 1048-1056. http://dx.doi.org/10.1016/j.energy.2010.12.003

[36] BERMEJO P, PINO F J, ROSA F. Solar absorption cooling plant in Seville, Solar Energy, 2010, 84, 1503-1512. http://dx.doi.org/10.1016/j.solener.2010.05.012 
[37] BARLEV D, VIDU R, STROEVE P. Innovation in concentrated solar power, Solar Energy Materials \& Solar Cells, 2011, 95, 2703-2725. http://dx.doi.org/10.1016/j.solmat.2011.05.020

[38] GOUHMAN G, KOUDRACHOVA M, MILEVSKAYA N, EYDINOVA F. Surfaces sélectives: propriétés optiques et estimation de l'efficacité énergétique dans l'application aux récepteurs solaires, Phys. Appl, 1980, 15, (3), 393-396. 10.1051/rphysap:01980001503039300 [39] WIKIPEDIA. Emissivité, Web site:

[40] http://fr.wikipedia.org/wiki/\%C3\%89missivit\%C3\%A9, 2015

[41] Rabl A. Collector efficiency and collector testing, in Active Solar Collectors and Their Applications, Oxford University press, New York, 1985.

[42] DUFFIE J A, BECKMAN W A. Collector tests: efficiency, incidence angle modifier, and time constant: in Solar Engineering of Thermal Processes, 4th ed., John Wiley \& Sons, Inc., 2013.

[43] GOSWAMI D Y, KREITH F, KREIDER J F. Off-normal incidence effects: in Principles of solar engineering, 2nd ed., Taylor \& Francis, 1999, pp. 139.

[44] FACAO J, OLIVEIRA A C. Numerical simulation of a trapezoidal cavity receiver for a linear Fresnel solar collector concentrator, Renewable Energy, 2011, 36, 90-96. http://dx.doi.org/10.1016/j.renene.2010.06.003

\section{How to cite this article:}

Ghodbane M, Boumeddane B, Said N. Design and xperimental study of a solar system for heating water utilizing a linear Fresnel reflector. J. fundam. appl. sci., 2016, 8(3), 804-825. 